\title{
Current Status of Sharps Waste Management in the Lower-Level Health Facilities in Tanzania
}

\author{
SAMWEL V. MANYELE ${ }^{{ }^{*}}$ and CHURCHIL M. MUJUNI \\ Department of Chemical \& Mining Engineering, College of Engineering and Technology, \\ University of Dar es Salaam, P.O. Box 35131, Dar es Salaam, Tanzania
}

\begin{abstract}
Sharps waste is part of infectious medical waste, management of which is a critical problem in Tanzanian health facilities. This study aimed at assessing the current status of sharps waste management in lower level health facilities (LLHFs) in Ilala Municipality in Tanzania. In this study a sample of 135 LLHFs (103 dispensaries, 13 clinics, 11 laboratories, and 8 health centers) was involved. The average number of workers per facility was 10, with positively skewed probability density function (up to 80 workers). The average patient-to-workers ratio was 5.87. About 59\% of the LLHFs improvised sharps waste containers (SWCs). Sharps waste was transported by hands in $77 \%$ of LLHFs leading to high risks of exposure to needle stick injuries. Boots, aprons and masks were among the personal protective equipment (PPE) missing in most LLHFs, while latex gloves that cannot protect workers from injuries caused by sharps waste were readily available. Most facilities stored sharps waste for about 72 hours (before treatment), which is beyond the recommended maximum storage time of 24 hours. About 39.3\% of LLHFs utilized on-site single-chamber incinerators for harps waste treatment, which are of poor design, have rusted mechanical parts, short and rusted chimneys, and without automatic flame ignition burners. It is concluded that sharps waste management in LLHFs is poor, which puts workers, the public and the environment at risk of exposure to blood-borne pathogens. It is, therefore, important that the municipality should establish a waste processing center which will collect and incinerate all sharps waste.
\end{abstract}

Key words: Sharps waste management, health facilities, infection, Tanzania

\section{Introduction}

Sharps waste is a form of medical waste composed of used sharp objects, which includes any device or object used to puncture or lacerate the skin in patient care. According to the World Health Organization, used items like syringes and needles, intra-venous (IV) tubing with needles attached, giving sets, scalpel blades, knives, lancets, blades and broken glass, form a class of medical waste known as sharps waste (WHO, 2005). Sharps waste contains items that can cause cuts or puncture wounds to healthcare workers. Whether sharps are infected or not, are considered highly dangerous and potentially infectious waste, due to their puncture or cutting property (Shanks \& Al-Kalai, 1995; Lymer et al., 1997; Kenned et al., 1998; Abu-Gad \& Al-Turki, 2001; Memish et al., 2002). Protection of health workers against HIV acquired from sharps waste is important (Henry et al., 1990; Henry \& Campbell, 1995; Ridzon et al., 1997).

Different types of sharps waste can be generated in all clinical institutions including hospitals, health centres, dispensaries and special clinics. Workers in support services linked to low level health facilities (LLHFs) such as laundries, waste handling and transportation service are often at risk (Jagger et al., 2003). Injection overuse and unsafe injections in the health facilities have been widely reported (Kane et al., 1999; Hutin et al., 2003). Workers in waste disposal facilities, scavengers, the public and more specifically the children are also at risk. The greatest risk posed by infectious waste is accidental needle stick injuries, which can be a source of Human Immunodeficiency Virus (HIV) infections (Henry et al., 1990; Henry \& Campbell, 1995; Gerberding et al., 1995; Ridzon et al., 1997; Jahan, 2005). Sharps wastes must therefore, be discarded at the point of origin into single use or reusable sharp waste containers (SWCs), which are sealed when full. Inappropriate design and/or overflow of SWCs and unprotected pits increase risk of exposure of the healthcare workers, sharps waste handlers and the community at large, to needle stick injuries.

In general, sharps waste management is a major problem in most developing countries due to its ever growing and endless generation. Though sharps waste constitutes a small fraction of the solid medical waste, the potential environmental and 
health hazards could be deleterious if not properly handled. Syringes and needles are of particular concern because they constitute an important part of the sharps waste and often are contaminated with body fluids from patients (Prüss-Üstün et al., 2003). In Tanzania, however, much attention has been paid to tertiary and secondary healthcare facilities located in urban areas where financial and human resources are more readily available, with limited efforts made to set-up sharps waste management plans for LLHFs. In particular, the management of sharps waste from mass and routine injection activities remains problematic as significant quantities of disposable or auto-disposable syringes and needles are generated (WHO, 2006).

Thus, there is need to assess the current situation of the sharps waste management in LLHFs in Tanzania. The main objective of this study was therefore, to evaluate sharps waste management in LLHFs in Ilala Municipality in Dar es Salaam City, Tanzania. The information generated from this is envisaged to enable policy makers and health workers to improve sharps waste management systems and hence improve infection prevention and control at work places in Tanzania. While previous studies focused on overall medical waste management (Kaseva \& Mato, 1999; Manyele et al., 2003; Manyele, 2004; Manyele \& Anicetus, 2006; Manyele, 2006) this study focused on sharps waste management which forms the most hazardous category of medical waste.

\section{Materials and Methods}

\section{Study area and sample size}

This study was carried out in Ilala Municipality in Dar es Salaam, Tanzania. Ilala Municipality covers $210 \mathrm{~km}^{2}$ comprising of 4 divisions and 17 wards. Ilala Municipality was selected based on the fact that most of the dispensaries are located within the city center and other closer suburbs (Ilala, Tabata, Vingunguti, Majumba Sita and Ukonga) such that they could be reached easily. The number of LLHFs involved in this study was 135 (including 103 dispensaries, 13 clinics, 11 laboratories and 8 health centres). The sharps waste management system of each LLHF was carefully studied, while documenting information on sharps waste generation, handling, transportation, treatment and disposal options. In addition, the nature of the sharps waste generated, type and performance status of existing incinerators was among the information collected.

\section{Data collection methods}

A simple and objective data collection checklist based on the WHO Sharps Waste Management Assessment Tool was used to collect data on sharps waste management in each LLHF ( http://www. who.int/water_sanitation_health/medicalwaste/). The respondents in this study involved medical officers (3), laboratory assistants (6), laboratory technicians (6), medical attendants (10), nurse midwives (11), assistant medical officers (16), nursing officers (23) and clinical officers (56). The study sought information (i) number of healthcare workers per facility and numbers of patients or clients visiting the LLHFs per day; (ii) patients to workers ratio for each facility; (iii) categories and composition of sharps waste generated in the facility; (iv) sharps waste segregation practices; (v) availability of personal protective equipment (PPE) during generation, transportation and treatment of sharps waste; (vi) storage conditions for sharps waste in facility; (vii) transportation of sharps waste within the facility; and (viii) sharps waste treatment facilities (incinerators) and final disposal facilities. In addition, secondary data, such as available documents, e.g., different reports from different departments of Ilala Municipality served as a source of information.

\section{Data analysis}

The collected data was sorted manually for all checklists and then entered into pre-created database in Microsoft Access and Microsoft Excel and analysed by Statistical Package for Social Sciences (SPSS 13.0) programme. The data analysis was initiated by invoking the descriptive statistics option and focusing on frequencies. The output contained graphical presentations (histograms and pie charts) and tabulated information.

\section{Results}

\section{Number of workers vs. patients in the LLHFs}

The majority of the facilities were owned by the private sector $(75.6 \%)$. Government and parastatal owned facilities accounted for $15.6 \%$ and $6.7 \%$ of the total facilities, respectively. In the 135 facilities surveyed, there were 1345 health workers who served about 6560 patients per day. The average number of health workers per facility was 10 (range $=2-84)$. There were more health workers in government owned facilities than in other facilities. In those facilities with number of workers below the mean, workers were not enough to manage their work including the sharps waste management 
as they were overwhelmed by large numbers of patients attending the facilities per day, for instance clinics and laboratories.

More patients (up to 350) were attended in health centres. These centres were likely to generate more sharps waste per day than the other facilities. Laboratories received the lowest numbers of patients (c. 50) per day compared to clinics and dispensaries. The overall patients-toworker ratio ranged between 1 and 22 patients per worker, indicating least loaded to heavily loaded health workers. The highest ratios were observed in government facilities. Most of the LLHFs were observed to have the ratio of patient to workers between 2 and 6 (mean= 5.9). In some facilities, however, the ratios were small, indicating lower numbers of patients, mostly observed in private LLHFs. It was observed that dispensaries had largest ratios, followed by laboratories and clinics, while lowest values were observed in health centres.

\section{Components of sharps waste generated and handled in the facilities}

Sharps waste generated and handled included syringes and needles, blood lancets, vacutainer needles, stitching needles, surgical blades, infusion sets, scalp vein needles and cannulas. Syringes and needles contributed the largest fraction of the sharps waste which was also produced in most of the LLHFs (Figure 1).

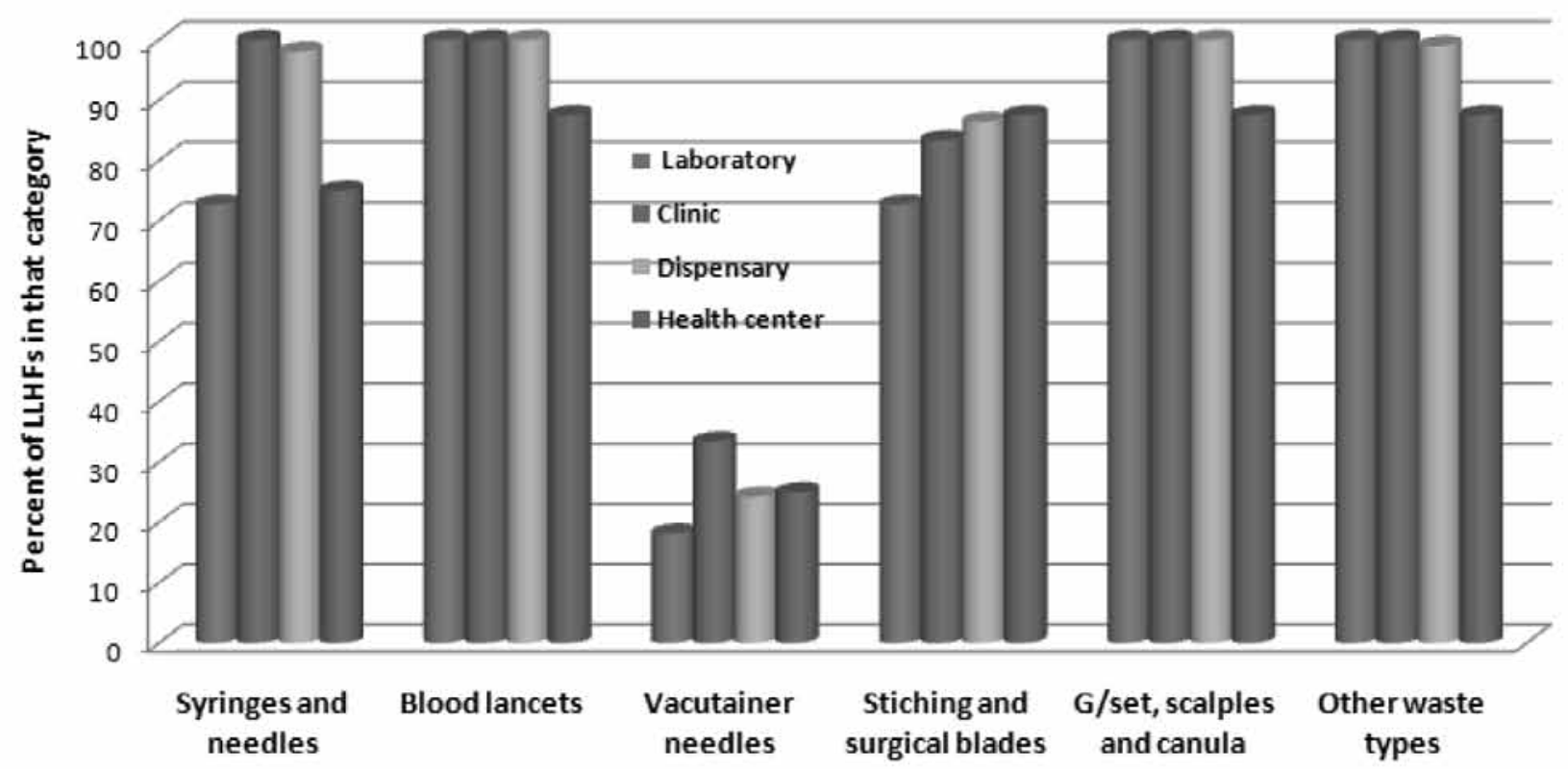

Figure 1: Major components of sharps waste generated and handled in the LLHFs

\section{Sharps waste segregation system}

Only $37 \%$ of LLHFs segregated sharps waste from other infectious waste immediately after use. Moreover, still a small fraction of LLHFs (33\%) segregated sharps waste by collecting the entire needle and syringe into a puncture proof container. In 135 facilities surveyed, only $10(7 \%)$ had written instructions for handling of sharps waste, among which, only $5(50 \%)$ of the facilities had written instructions available (Figure 2). Moreover, 5 (50\% of the LLHFs with written instructions) had posters which were displayed openly. This fraction of LLHFs comprised only $6 \%$ of the total number of facilities in Ilala Municipality. Only $4 \%$ of the facilities had waste management guidelines from the Ministry of Health. These guidelines included instructions on sharps waste management. Three percent of the LLHFs provided instruction on proper sharps waste management to the health workers. However, there was a low (3\%) adherence to the guidelines. 


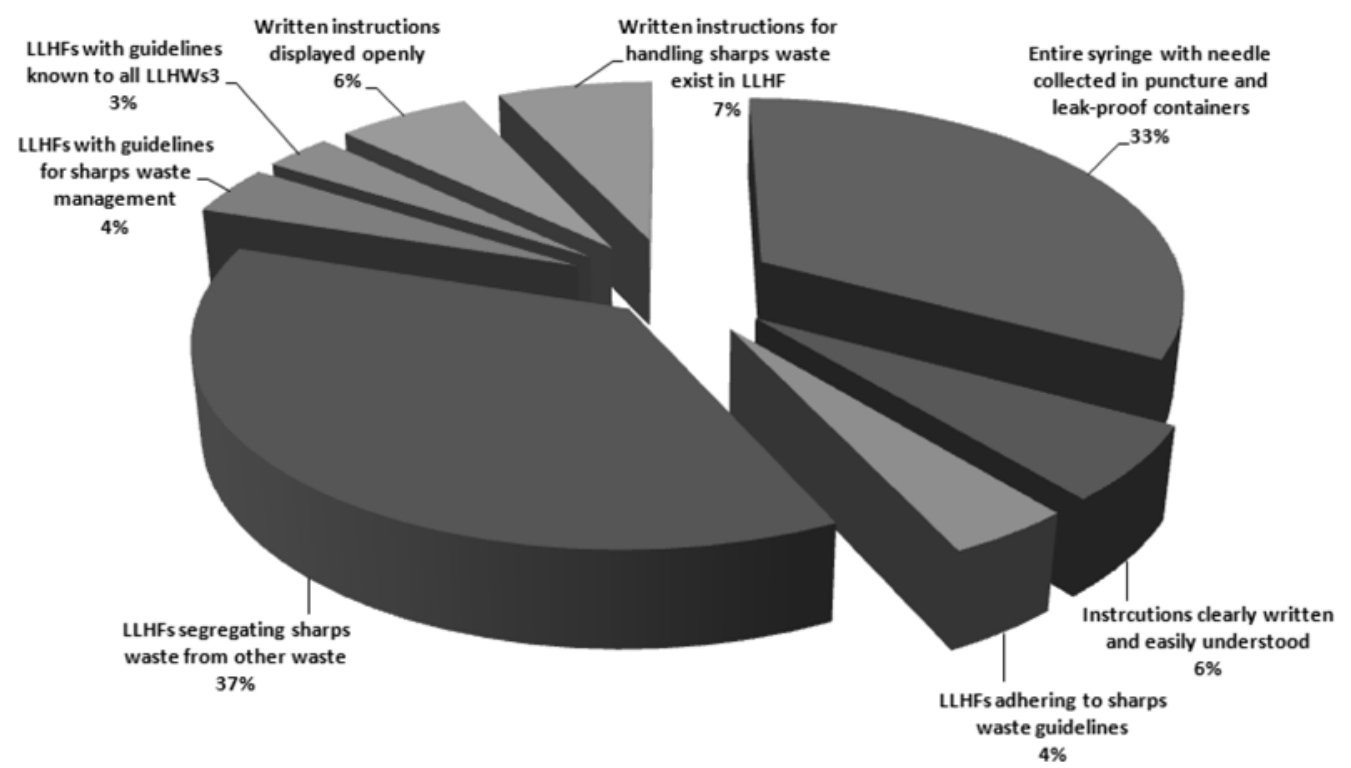

Figure 2: Components of the comprehensive sharps waste segregation system in LLHFs

\section{Sharps waste containers}

Several types of sharp waste containers (SWCs) were observed in LLHFs. Most of SWCs found in use were locally made within the facilities. Improvised SWCs were observed in $80(59 \%)$ of the LLHFs. The UNICEF /WHO safety boxes were observed in $31(23 \%)$ of the LLHFs, while $24(18 \%)$ facilities used Expanded Programme on Immunization (EPI) safety boxes. The standard filling capacity of the sharps containers, that is, $3 / 4$-full, was not followed, such that SWCs were overfilled leading to spreading of sharps waste on the floor.

\section{Protective personal equipment (PPE) for handling} sharps waste

Only a quarter (25\%) of the facilities was providing boots to health workers handling sharps waste, while only $10 \%$ of facilities had plastic aprons. Only heavy duty gloves were available in $40 \%$ of the LLHFs. Inappropriate use of protective gears was observed in most facilities.

Almost all LLHFs had latex gloves in injection rooms and clinical coats in clinician's consultation rooms and laboratories. Majority of health workers were observed to handle sharps waste without PPE. Among 123 laboratory workers observed in this study, 87 (70.7\%) were in casual dressing. Similarly, among 93 clinicians observed, 74 (79.6\%) were in casual dressing without apron, mask, or boots, as summarized in Figure 3.

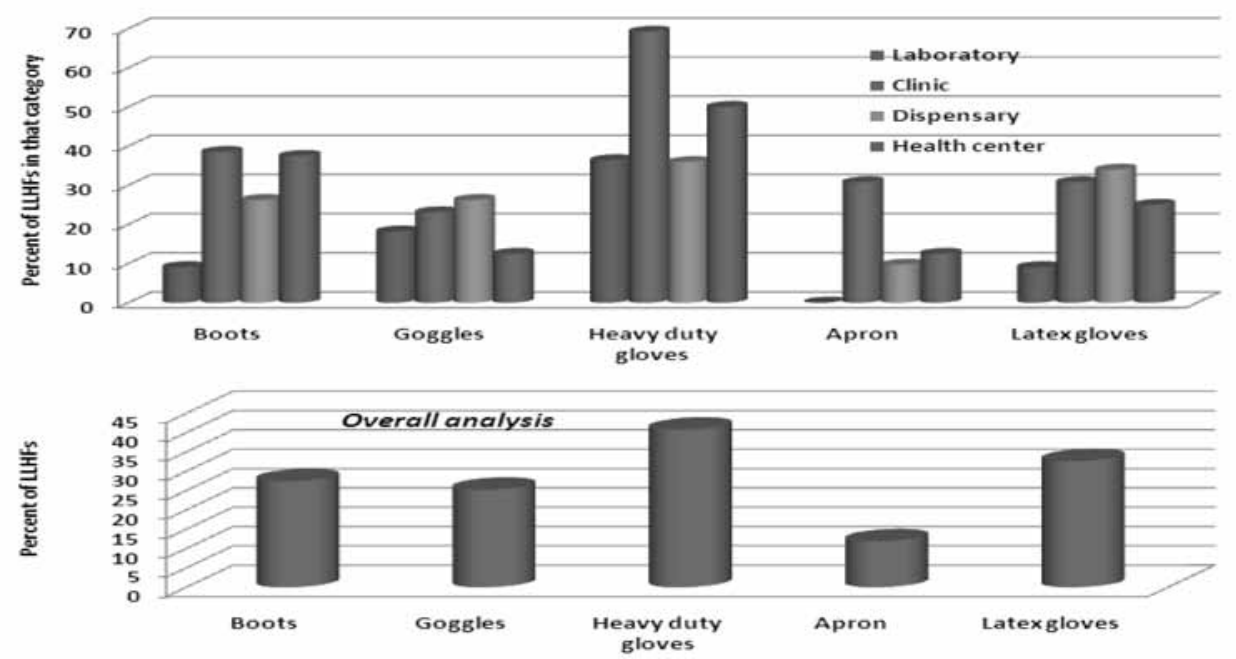

Figure 3: Availability of PPE in lower-level health facilities 


\section{Storage of sharps waste}

In the 135 LLHFs, 40 (29.6\%) had storing facilities for sharps wastes within their premises. However, only $5(12.5 \%)$ facilities stored sharps waste for less than 24 hours, and 4 (10\%) stored sharps waste up to 48 hours, while the rest stored sharps waste for more than 72 hours before disposal. When assessed according to health facility category, only few laboratories stored sharps waste for more than 72 hours, while $25 \%$ of each of the other categories stored for $\geq 72$ hours. Among 40 facilities with sharps waste storage bays, only one adhered to storage procedures, that is, sharps waste are labelled and enclosed in special bags with protected storage area. About $31 \%$ of the LLHFs stored sharps waste for more than 72 hours. Meanwhile, the facilities storing sharps for 24 and 48 hours were minimal. Assessment of the containers based on puncture and leak proof conditions and whether the waste storage containers are kept with colour coding or bearing a biohazard sign/symbol, revealed different adherence levels, such that clinics, health centres, dispensaries and laboratories scored 37.5\%, 25.0\%, $11.7 \%$ and $9.1 \%$, respectively.

\section{Transportation and disposal of sharps waste}

In $78(57.8 \%)$ LLHFs, health workers carried SWCs manually (by hands) instead of using special trays or wheelbarrow. In very few LLHFs ( 2 out of 103 dispensaries and $12 \%$ of the clinics), health workers used special trays. The remaining proportion of the facilities used other means. About three quarters $(73.4 \%)$ of LLHFs practiced on-site treatment of sharps waste. This include exercising on-site incineration $(39.3 \%)$, open burning on the ground $(7.4 \%)$, open burning in a hole or enclosure $(10.4 \%)$, burying the waste $(9.5 \%)$, or dumping in a sharps pit (4\%) within the facility. The remaining $29.4 \%$ of LLHFs practiced off-site treatment of sharps waste. Of the total LLHFs surveyed, 53 $(39.3 \%)$ had on-site incinerators. All incinerators were low-cost single-chamber types, except one dispensary which has installed a double chamber incinerator. Based on health facility categories, $32 \%$ of dispensaries, $26 \%$ of laboratories, $23 \%$ of health centres and $13 \%$ of clinics were using single chamber incinerators. None of the facilities had a high-tech incinerator (that is, incinerator unit with air pollution control devices, temperature control, flame ignition burner).

When probed on the disposal methods used in case of malfunctioning incinerators, the respondents indicated that they resort to burying in secured pits. About $25 \%$ of the health centres indicated that they also practice dumping in pit latrines. Open dumping was observed in $5 \%$ of the dispensaries, while other dispensaries indicated that sharps waste was left in piles on the ground within the health facility. Use of sanitary landfill was observed only in $2 \%$ of the dispensaries, mainly due to lack of standard sanitary landfills in the city. It was further observed in some of the LLHFs that the process of incineration was performed during night hours to hide air pollution caused by visible plumes of fumes and dusts. However, community complaints were still being registered due to nuisances emanating from the incinerators. It was further observed that the incinerators used in $17 \%$ of LLHFs have short chimneys, which release fumes and fine dusts near the ground increasing ground level pollutants concentration in the air reaching the neighbouring communities.

Most of the mechanical features of the incinerators surveyed in the LLHFs were not maintained in good conditions, such that, $28.9 \%$ of the incinerators were observed to have poor closing efficiency, $27.4 \%$ had corrosion on major parts, while $17.3 \%$ had chimneys which were either too short or destroyed by rust (Figure 4). A quarter (25\%) of the LLHFs had incinerator housing parts which were cracked and partly collapsed.

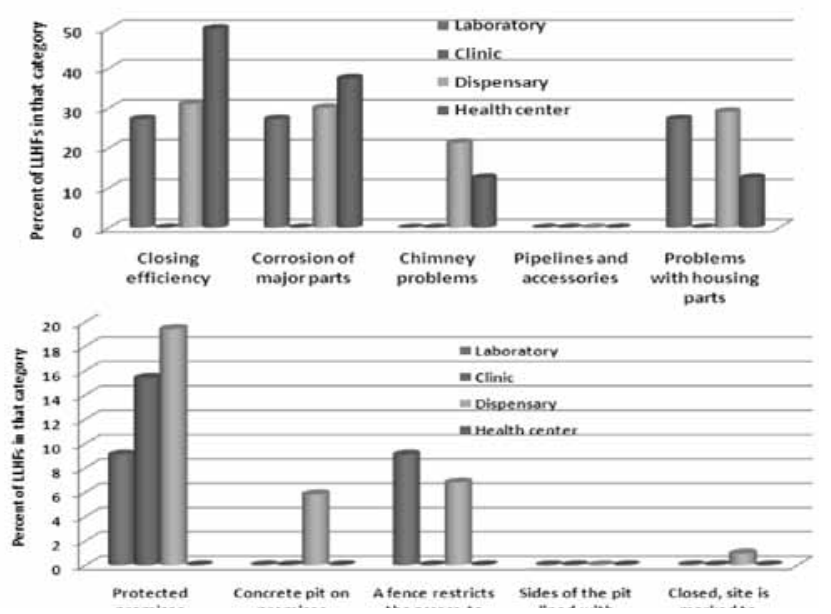

Figure 4: Mechanical features of incinerators and protection of waste disposal areas in LLHFs

Most incinerators had mechanical problems. For a case of dispensaries, protected incinerator premises, concrete pits for ashes, and fencing the sharps waste pit area, was observed in $20 \%, 5 \%$ and $6 \%$ respectively. Challenges faced by LLHFs in sharps waste management were categorized into two parts: required inputs for each stage of sharps waste 
management and the problems encountered. The challenges included inadequate personnel with skills on sharp waste management, collection of waste not well planned, and manual transport of waste in boxes, storage bays accessible to rodents, pets, rains and scavengers and poorly designed small singlechamber incinerators.

\section{Discussion}

Proper sharps waste management is of paramount importance for the control of blood borne diseases. In this study, almost all LLHFs generated syringes and needles and blood lancets. However, not all facilities generated stitching and surgical blades, giving sets, scaples and canulas. The study shows that there is a wide range of types of sharps waste generated in LLHFs in Tanzania. Sharps waste management involves placing SWCs in each generation point (like injection area), use of puncture proof containers like special safety boxes, and observing the fill lines for sharps containers (3/4 full) without allowing overflow and controlling the spread of sharps waste within and around the health facility. Overflowing sharps injection equipment and sharps waste lying inside and around the health facility exposes workers and the public to accidental needle-sticks, as observed in this study and also based on reports from literature (Shanks \& Al-Kalai, 1995; Lymer et al., 1997; Kenned et al., 1998; Abu-Gad \& Al-Turki, 2001; Memish et al., 2002).

All sharps should be disposed of immediately after use, in other words, after generation. Used syringes and needles can be disposed of into a safety box followed by incineration without tempering with the box. Syringes with needles attached should be directly placed into a safety box or other approved sharps receptacle immediately after use. An ideal sharps receptacle is puncture-resistant and liquidproof and has an opening that is small enough that a hand cannot fit into it and that contents cannot be retrieved from it. Improvised SWCs do not have such NSI prevention features and should be avoided. Use of safety boxes and other proper SWCs protects support staff, waste handlers and waste transporters (Jagger et al., 2003).

Inefficiency was observed in the sharps waste segregation system in the LLHFs. Sharps waste segregation is not performed comprehensively since the sharps waste are still being mixed with other waste types in waste containers, as observed in the dumping or burning sites located in LLHFs. Segregation of sharps waste observed in most of LLHFs was mainly concentrated in collection and transportation of sharps waste for which demarcation was made between infectious and non-infectious wastes, but mixed at the disposal facility (incinerator storage bay, dumping areas and burying pits). Even where sharps waste segregation is properly done, no written instructions for handling of sharps waste in the facilities were observed. On the other hand, none of the LLHFs was observed to be totally adhering to sharps waste management guidelines indicated by the observed lower number of LLHFs adhering to the guidelines. The comprehensive use of the puncture and leak proof containers in the healthcare facilities were mainly observed in injection and laboratory sections, while other units like minor theatre and dressing areas, such containers were not comprehensively used, instead sharps waste were mixed with other wastes and overfilled containers.

The main reason for overfilling the safety boxes and increased use of improvised SWCs is lack of enough supplies for safety boxes due to affordability and lower priority for use of safety boxes. This can also be attributed to lack of knowledge among the workers in the LLHFs.

The improper management of sharps waste in the LLHFs is directly connected to transmission of blood-borne diseases such as HIV (Amstrong et al., 1995; Bell, 1997), Hepatitis B (Gerberding et al., 1985; Kaneko et al., 1989; Carrilho et al., 2004) and Hepatitis C (Polish et al., 1993; Alter, 1997). This problem has been reported in many studies, necessitating extra efforts in protecting the health workers and the community (Gerberding et al., 1995; Jahan, 2005). The best way to prevent healthcare workers from exposure to such infections is to insist the proper management of sharps waste and providing PPE. Sharps waste handlers should wear PPE appropriate to the risks (e.g., lab coat, gloves, safety glasses, aprons, protective footwear, and heavy duty gloves) (Konig, 1992; CDC, 1998). Most of the LLHFs in Ilala Municipality lack plastic aprons, masks and protective goggles, gloves and boots. Many researchers on sharps waste management have insisted on the use of PPE (Konig, 1992). Needles and other sharp instruments should be handled with great care and disposed of in approved sharps containers. As a rule, sharps waste generators should not recap, bend or break used needles.

Storage of sharps waste is necessary before further action is taken. The sharps waste storage within a health facility should be located close to the treatment units. The storage premise is required to be large enough to handle sharps wastes produced 
by the respective healthcare facility. This study has revealed problems ranging from longer storage times to lack of storage facilities. The LLHFs should assign central segregated storage for potentially infectious medical waste awaiting on-site or offsite treatment and disposal. Without refrigeration in warm climates, maximum storage time is 24 hours in the hot season, 48 hours in the cool season (https://www.who.int/water_sanitation_health/ medicalwaste/).

The primary purpose of treatment and disposal is to protect public health through the destruction or isolation of hazardous health care waste from people, grazing animals and disease vectors. Currently, there is a rising national environmental protection standards and social expectations on medical waste treatment, which must be met by LLHFs. Improper sharps waste treatment and disposal results into risk to healthcare workers, the public and environmental pollution.

Removal of ashes from incinerators is conducted irregularly in most LLHFs, such that ashes are removed after long time intervals. For example, most of LLHFs take more than a week to remove ashes from the incinerators. This study have revealed that after removing the ashes from incinerators, this waste is buried in secured pits in some facilities, while other facilities leave the ashes piled on the ground within the health facility. Maintaining an incinerator is another critical issue. A qualified official must inspect the incinerator every 6 months using the following criteria: masonry inspection and repair; metal and chimney inspection and repair; ash pit; and site maintenance.

Disposal of incinerator ashes by burying depends on degradation to harmless materials. Burying has a disadvantage of leaching of harmful components from such disposal sites and consequent contamination of ground water or extraction from soils and concentration in plants. Plastics connected to syringes and needles are synthetic compounds not biodegradable by indigenous micro flora and fauna. Therefore, such substances stay in the environment for extended period (leading to accumulation) (Singh \& Prakash, 2007; Gidarakos et al., 2009; Santoleri, 2009). Also, some of the sharps waste materials have casinogenic substances, which are not environmentally friendly, indicating that disposing of sharps waste by burying continue the discharges of pollutants into the ground water and soil (Allsopp et al., 1999).

Water pollution due to the sharps waste management is a common problem observed in areas with high water table. Measures such as cleaning and disinfecting the vehicle after use, training of all staff on handling, unloading and loading, transportation and disposal of yellow bags, encouraging staff to wear protective gears, are among the efforts that should be taken. Other measures should include restricting vehicles used to be for carriage of yellow bags only, and provision of consignment note for vehicle collecting yellow bags to disposal point.

Sharps waste management is a major problem in most LLHFs in Ilala Municipality and the rest of the country due to its ever growing and endless generation of such waste coupled with poor management. Improper sharps waste disposal methods, which are still used in LLHFs, pose greatest health risks to the health workers and the public. Incineration is still the most prominent sharps waste treatment option in LLHFs and other health facilities in Tanzania. It is recommended that for all LLHFs to have high quality incinerators that can destroy sharps waste. The municipality should identify a single off-site incineration facility where all the LLHFs shall direct their sharps waste for destruction. There is a need for the Ministry of Health to intervene the sharps waste management in LLHFs similar to efforts directed in higher level facilities in the past. The required intervention is in the form of training, backstopping and reinforcement of regulations.

Received 22 May 2010

Revised 20 August 2010

Accepted 3 September 2010

\section{References}

Abu-Gad, H.A. \& Al-Turki K.A. (2001) Some epidemiological aspects of needlestick injuries among the hospital health care workers: Eastern province, Saudi Arabia. European Journal of Epidemiology 17, 401-407.

Allsopp, M., Costner, P. \& Johnston, P. (2001) State of Knowledge of the Impacts of Waste Incinerators on Human Health. Environmental Science \& Pollution Research 8, 141-145.

Alter, M.J. (1997) The epidemiology of acute and chronic hepatitis C. Clinical Liver Disease 1, 569.

Bell, D.M. (1997) Occupational risk of human immunodeficiency virus infection in healthcare workers: an overview. The American Journal of Medicine 102 (Suppl 5B), 9-15.

Carrilho, F.J., Moraes, C.R., Pinho, J.R.R., Mello, I.M.V.G.C., Bertolini, D.A., Lemos, M.F., 
Moreira, R.C., Bassit, L.C., Cardoso, R.A., Santos G.R. \& Da Silva, L.C. (2004) Hepatitis $B$ virus infection in Haemodialysis Centres from Santa Catarina State, Southern Brazil: Predictive risk factors for infection and molecular epidemiology. BMC Public Health 4: 13.

CDC (1998) Centers for Disease Control and Prevention: Recommendations for prevention and control of hepatitis $\mathrm{C}$ virus (HCV) infection and $\mathrm{HCV}$-related chronic disease.

Gerberding, J.L., Hopewell, P.C., Kaminsky, L.S. \& Sande, M.A. (1985) Transmission of hepatitis B without transmission of AIDS by accidental needle stick. New England Journal of Medicine, 312, 56.

Gidarakos, E., Petrantonaki, M., Anastasiadou, K. \& Schramm, K.W.J. (2009) Characterization and hazard evaluation of bottom ash produced from incinerated hospital waste. Journal of Hazardous Materials 172, 935-942.

Henry, K. \& Campbell, S. (1995) Needle stick/sharps injuries and HIV exposures among health care workers: national estimates based on a survey of U.S. hospitals. Minnesota Medicine 78, 1765-1768.

Henry, K., Campbell, S., Jackson, B., Balfour, H., Rhame, F., Sannerud, K., Pollack, S., Sninsky, J. \& Kwok, S. (1990) Long-term follow-up of health care workers with work-site exposure to human immunodeficiency virus, (letter to the editor). Journal of American Medical Association 13, 1765-1766.

Hutin, Y.J.F., Hauri, A.M., \& Armstrong, G.L. (2003) Use of injections in healthcare settings worldwide: Literature review and regional estimates. British Medical Journal 327, 1075

Jagger, J. (1996) Reducing occupational exposure to blood-borne pathogens: where do we stand a decade later. Infection Control Hospital Epidemiology 17(9), 573-575.

Jahan, S. (2005) Epidemiology of needlestick injuries among health care workers in a secondary care hospital in Saudi Arabia. Annals of Saudi Medicine 25, 233-238.

Kane, A. Lloyd, J. Zaffran, M., Simonsen, L. \& Kane, M. (1999) Transmission of hepatitis $\mathrm{B}$, hepatitis $\mathrm{C}$ and human immunodeficiency viruses through unsafe injections in the developing world: model-based regional estimates. Bulletin of World Health Organization 77, 801-807.

Kaneko S., Feinstone, S.M. \& Miller, R.H. (1989)
Rapid and sensitive method for the detection of serum hepatitis B virus DNA using the Polymerase Chain Reaction technique. Journal of Clinical Microbiology 27, 19301933.

Kaseva, M.E. \& Mato, R.R.A.M. (1999) Critical Review of Industrial and Medical Waste Practices in Dar es Salaam City. Resource, Conservation and Recycling 25, 271-287.

Kenned, M., O'Reilly, D. \& Mah, M.W. (1998) The use of a quality-improvement approach to reduce needlestick injuries in a Saudi Arabian hospital. Clinical Performance and Quality Healthcare 6, 79-83.

Konig, M., Bruha, M. \& Hirsch, H.A. (1992) Perforation of surgical gloves in gynecologic operations and abdominal Cesarean section. Geburtshilfe Frauenheilkd 52, 109 -112.

Lymer, U.B., Schutz, A.A. \& Isaksson, B. (1997) A descriptive study of blood exposure incidents among health care workers in a university hospital in Sweden. Journal of Hospital Infections 35, 223-235.

Manyele, S.V. \& Anicetus, H. (2006) Management of Medical Waste in Tanzanian Hospitals. Tanzania Health Research Bulletin 8, 177-182

Manyele, S.V. (2004) Effects of Improper Hospital Waste Management on Occupational Health and Safety. African Newsletter on Occupational Health and Safety 14, 30-33.

Manyele, S.V. (2006) Medical waste Management in Tanzania: Current Situation and the Way Forward. African Journal of Environmental Assessment and Management, 8, 74 - 99.

Manyele, S.V., Anicetus, H. \& Bilia, M.H. (2003) Globalization and its effects on Medical Waste Management in Tanzania. IET Annual Conference and General Meeting, AICC Arusha, Tanzania, pp. 76-92.

Memish, Z.A., Almuneef, M. \& Dillon, J. (2002) Epidemiology of needlestick and sharps injuries in a tertiary care center in Saudi Arabia. American Journal of Infection Control, 30(4), 234-241.

Polish, L.B., Tong, M.J., Co, R.L., Coleman P.J. \& Alter, M.J. (1993) Risk factors for hepatitis C virus infection among health care personnel in a community hospital. American Journal of Infection Control, 21(4), 196-200.

Ridzon, R., Gallager, K., Ciesielski, C., Mast, E.E., Ginsberg, M.B., Robertson, B.J., Luo, C.C. \& DeMaria, A. (1997) Simultaneous transmission of Human Immunodeficiency 
virus and Hepatitis $\mathrm{C}$ virus from a needlestick injury. New England Journal of Medicine 336, 919-922.

Santoleri, J.J. (1985) Design and Operating Problems of Hazardous Waste Incinerators. Environmental Progress 4, 246-251.

Shanks, N.J. \& Al-Kalai, D. (1995) Occupation risk of needlestick injuries among health care personnel in Saudi Arabia. Journal of Hospital Infections 29, 221-226.

Singh, S. \& Prakash, V. (2007) Toxic environmental releases from medical waste incineration:
A review. Environmental Monitoring and Assessment 132, 67-81.

WHO (2005) Management of Solid Healthcare Waste at Primary Healthcare Centres, A DecisionMaking Guide. World Health Organization, Geneva.

WHO (2006) Management of Waste from Injection Activities at District Level, Guidelines for District Health Managers. World Health Organization, Geneva.

World Bank (2000) Health Care Waste Management Guidance Note. World Bank. 